\title{
Rice farmer's poverty and its determinants: evidence from Dogofiri village of Office du Niger zone in Mali
}

\author{
Brahima Coulibaly ${ }^{1}$ Shixiang Li $^{2 *}$ (D) Zhanqi Wang ${ }^{3}$
}

${ }^{1}$ School of Public Administration, China University of Geosciences, Wuhan, Hubei, China.

${ }^{2}$ School of Public Administration, Mineral Resources Strategy and Policy Research Center, China University of Geosciences, Wuhan, Hubei, China. E-mail: lishixiang@cug.edu.cn. "Correspondence author.

${ }^{3}$ School of Public Administration, China University of Geosciences, Wuhan, Hubei, China.

ABSTRACT: The aim of this research was to contribute to a better understanding of rice farmer's poverty of Office du Niger (ON) in Mali at village-level. Data were collected through survey with 110 head family farms in the village of Dogofiri. Quantitative data were analyzed using descriptive statistics. Multiple linear regression models were used to analyze the main determinants of poverty. Results indicated that the factors of physical capital and human capital as well as government policy have a significant influence on the poverty of family farms through production, age, family size, education and health support, agricultural credit and water fees. Policies aimed to improve the family farm's income and boosting rice production to alleviate poverty ought to be based on these factors.

Key words: rice farmer, poverty, determinants, Office du Niger, Mali.

A pobreza dos agricultores de arroz e seus determinantes: evidências da aldeia de Dogofiri na zona do Office du Niger, Mali

RESUMO: O objetivo desta pesquisa é contribuir para uma melhor compreensão da pobreza dos produtores de arroz do Office du Niger $(O N)$, no Mali, ao nível das aldeias. Os dados foram coletados por meio de pesquisa em 110 propriedades familiares da aldeia de Dogofiri. Os dados quantitativos foram analisados por meio de estatística descritiva. Modelos de regressão linear múltipla foram utilizados para analisar os principais determinantes da pobreza. Os resultados indicaram que os fatores de capital fisico e de capital humano, bem como a politica governamental, influenciam significativamente na pobreza das propriedades familiares por meio da produção, idade, tamanho da família, educação e apoio à saúde, crédito agrícola e taxas de água. Políticas destinadas para melhorar a renda da agricultura familiar e aumentar a produção de arroz para atenuar a pobreza devem basear-se nesses fatores.

Palavras-chave: pobreza rural, política de alivio da pobreza, Office du Niger, Mali.

\section{INTRODUCTION}

Poverty is rampant around the world (World Bank, 2018). Poverty varies from a developed country to a developing country. It also varies within the same country from urban areas to rural areas. At the national level, each country has adopted its own strategy to combat poverty. The Government of Mali has expressed in recent years its willingness to make the fight against poverty the priority of all development priorities. That commitment was spelled out in the implementation of the different generations of the poverty Reduction Strategy Framework (CSLP). Poverty alleviation was given high priority throughout Mali's strategic framework for poverty alleviation (CSLP) adopted by the Government of
Mali in May 2005. The achievement of (CSLP) objectives will largely depend on the performance of the agricultural sector. The Office du Niger (ON) was targeted to meet these challenges because of its abundant irrigable land.

With the economic liberalization of the 1980s and 1990s and the rehabilitation of major infrastructures, farms intensified their production and the ON became a pole of agricultural growth (COULIBALY \& BELIERES, 2006). The rice programs of the $\mathrm{ON}$ are of vital importance to national food security in Mali. It provides about 810,000 tons of paddy, or $40 \%$ of domestic production (VANDERSYPEN et al., 2008). Integration of agriculture and livestock in $\mathrm{ON}$ is a good means of combating farmer's poverty (DOUMBIA et al., 
2012). NERICA rice varieties by its high yield per hectare contribute to the improvement of income of farmer owning small farms (DIBBA et al., 2012).

At the $\mathrm{ON}$, the system is expensive to develop and the production costs are high because of the hydraulic fee, use of imported chemical fertilizers and contract labor (WANNEHAIN \& JANIN, 2012). In the Macina area, the costs of fertilizers and water charges represent two-thirds of the cost of production (MATHER \& KELLY, 2012). The good investment related especially to good management of means of production policies in $\mathrm{ON}$ can alleviate poverty (ROUDART \& DAVE, 2017). In Office du Niger zone where farmers practice irrigated rice cultivation; poverty is less accentuated compared to other rural areas where crops depend on rains (BELIERES et al., 2011). They noted better living conditions of farmers in irrigated areas compared to other parts of the rural Mali and the region of Ségou. Poverty is very popular in rural areas in Mali; although, there are inter-regional differences linked to past public investment. The most efficient area in Mali in terms of agricultural production (Macina) is; therefore, relatively poor compared to the national and international standard indicators.

The best-equipped farms in production factors have tend to postpone sales in times of welding due to more favorable prices. The poorest should sell part of their production shortly after harvests, to pay their debts (WANNEHAIN \& JANIN, 2012). Farm debt is a major issue for farmers' sustainable access to financial services and indebtedness is a phenomenon that affects all types of farms of $\mathrm{ON}$ (KONE et al., 2004). Causes of the debt are related to the misappropriation of the loan object, the nonobservance of the agricultural calendar by insufficient agricultural equipment and the lack of organization of the paddy rice storage system. Moreover, the difficulties of learning and adapting to the policy of liberalization of the rice sector, the rainfall risks and the lack of consultation between the main financial institutions of the place are also important causes (KONE et al., 2004).

While the Rice Initiative has reduced the cost of fertilizer and facilitated farmers' access to credit, the use of fertilizer has not increased. About $90 \%$ of farmers around the world are smallholders. To this end, promoting innovation in the agricultural field is essential to ensure food security, reduce poverty and hunger. Appropriate innovation strategies for small-scale agriculture are needed to ensure the competitiveness and sustainability of rural activity (BAGGIO \& KHUL, 2018). In ON zone, family farms contributed to strong agricultural growth by changing their practices in order to intensify and diversify their production (COULIBALY et al., 2006). The head of the agricultural household who has several livelihood activities is less likely to be poor. These activities increase the incomes of farmers, raise their purchasing power and ensure their well-being (OYINBO \& OLALEYE, 2016).

Although, many studies have already been performed, more studies are needed to determine ricefarmers poverty in $\mathrm{ON}$ at villages level. Research needs to address on poverty in all the hydraulic systems. These studies must be concerned with new farming practices in land management, inputs and harvest. These practices often violate the laws that govern the ON and lead to the farmer's poverty. The purpose of this study is to highlight the causes of poverty of rice farmers in the village of Dogofiri in Office du Niger area, to highlight some bad practices that characterize rice cultivation making ineffective government actions through the subsidy of agricultural inputs including fertilizer. This study contributed to the literature on the poverty of rice farmers in the $\mathrm{ON}$ area, based on a sample of the heads of family farms living in the village of Dogofiri in the Kouroumari area. This research was identified as being useful to the government to achieve its objective of making the Office du Niger and irrigated rice farming elements of poverty alleviation at the national level.

\section{MATERIALS AND METHODS}

\section{Study area}

Office du Niger is the largest and oldest irrigated perimeter in West Africa. $\mathrm{ON}$ is a Malian parastatal company managing one of the largest irrigation schemes in West Africa. The ON was developed from the 1930s in the inner delta of the Niger River. Since independence, ON became an enterprise of the Malian State on May 19, 1961. ON was to be the main supplier of cotton to the industries of colonial France, the rice granary of West Africa and the place of technical innovations. The village of Dogofi ri which is the subject of this study is located in Kouroumari. Dogofiri is limited to the North East by the municipality of Nampalari, to the East by the municipality of Kareri, to the South East by the municipality of Diabaly and to the West by the municipality of Sokolo (Figure 1). Since 1996, the village of Dogofiri was erected as a rural municipality. According to unpublished data from Administrative Electoral Census, population of Dogofiri commune was approximately 20, 800 inhabitants in 2016. 


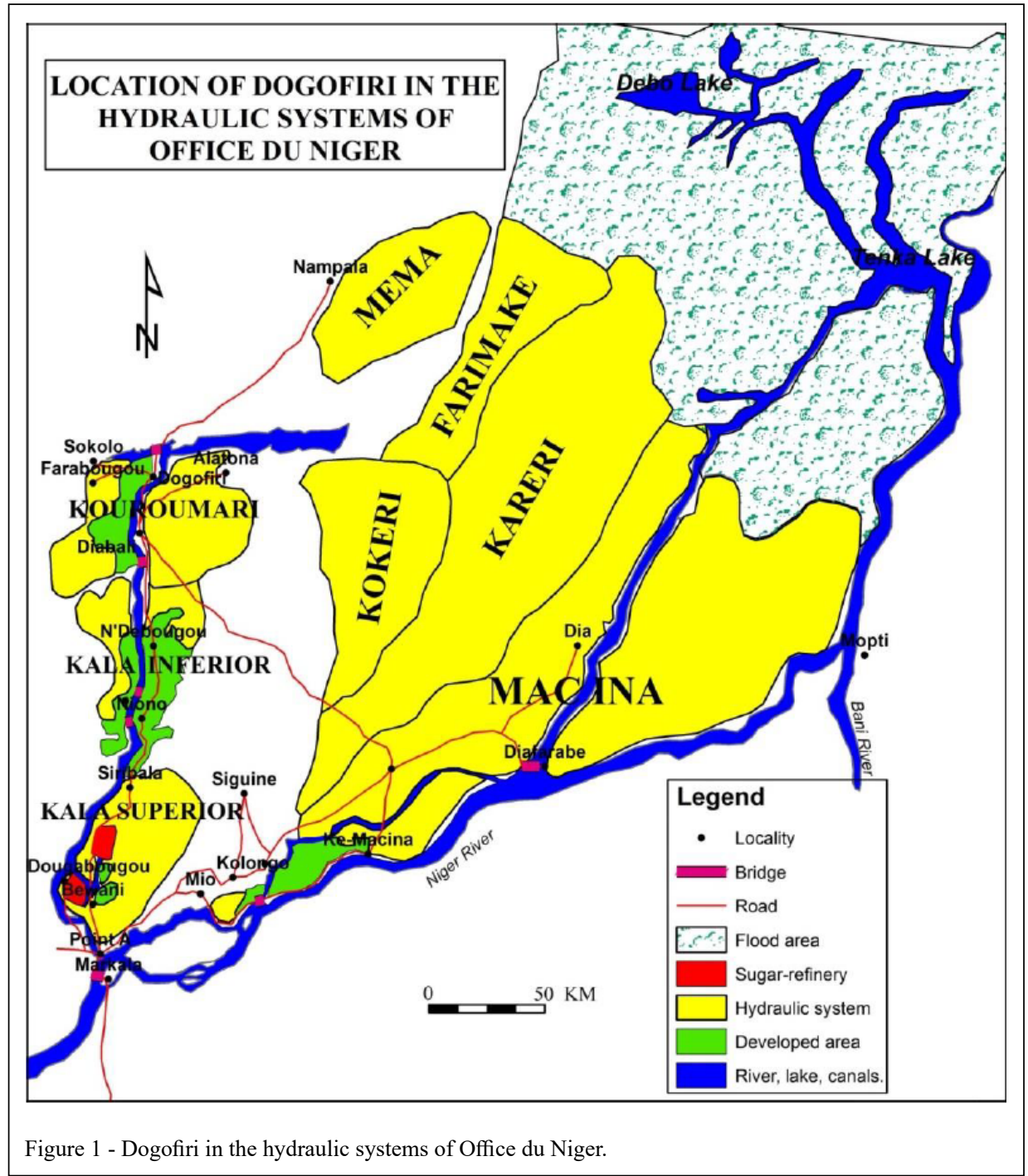

\section{Sampling}

Dogofiri village was chosen in this study because it's le chef lieu de la commune. In the village, 137 family farms are the beneficiaries of the land of $\mathrm{ON}$ for growing rice. These family farms pay water fees, the deadline for which is March 31 at the end of the crop year. The heads of these family farms formed our sample. The area of land allocated by ON to the village is 329.50 ha. The average land acreage per family is about 2.40 ha. Our survey was conducted in January 2018 after the harvest. Based on the list of family farms held by the villager association (AV) which groups only the beneficiaries of the lands of $\mathrm{ON}$; we numbered the name of each head of family farm on pieces of paper. Random sampling was used to give each farmer the same probability of being selected. Then, 120 heads of family farm was selected. We realized later that some farmers have left the village because they were excluded due to nonpayment of water fees. However, 110 heads of family farm, with a frequency of $80.29 \%$, answered our questionnaire. That was consistent with the statistical principles in which, the sample should represent at least $10 \%$ of the size of the general set and contain at least 30 units (SAVARD, 1978).

Method, data collection and analyze

Quantitative method was used with data collection carried out in January 2018 using 
a questionnaire. Each questionnaire included 75 questions. Respondents were male (91.8\%) and female $(8.2 \%)$ and $31.8 \%$ were between $44-55$ years old. Young people old from 15 to 25 represented $0.9 \%$. The questionnaire was structured with closed and open questions about production, means of production, income and poverty.

To find out the determinants of poverty, the key factors were analyzed, including lack of physical capital, human capital, natural resource and technology.

\section{Conceptual framework of analyzing poverty in Dogofiri village}

To find out the determinants of poverty, the key factors were analyzed, including physical capital, human capital, technology and government policy according to this general formula:

$\mathrm{Y}=\alpha+\beta 1$ Cphy $+\beta 2$ Chum $+\beta 3 \mathrm{Tec}+\beta 4 \mathrm{Gp}+\varepsilon$

$Y$ indicates family farm's income (representing poverty). The incomes are based primarily on the production of rice. Cphy means physical capital. Physical capital consists of land allocated by the Office du Niger, production, agricultural credit and equipment. Physical capital is very important in this study because in the Office du Niger zone, land pressure became a major constraint leading to a strong differentiation between farms. The lack of equipment is also mentioned by many farmers as a constraint to the production. Chum indicates human capital. Human capital is very important because human is at the beginning and end of any process of economic development. Farmers' educational level, population growth, age and sex are variables that can affect the income of family farms. The women who are part of our sample were widows who inherited the land of their late husband. The land was attributed to the head of the family. In Malian tradition and according to the law, the woman is not head of the family; therefore, she should not own the land. In fact, there is a strong demand for labor in $\mathrm{ON}$ area despite the arrival of people looking for farming activities. Tec means technology and deals with agricultural inputs, the drainage schemes and rice processing. Technologies increase production and yield per hectare by increasing the income of the farmer. These technologies create added value that improve the living conditions of farmers. Gp is related to government policy. According to Decree No. 96-188 / P-RM on the organization of the management of land allocated to the Office du Niger, land is the property of the State which has entrusted its management to the Office du Niger. The Implementing Decree of land management in $\mathrm{ON}$ determines the attribution methods of plots to the families assimilate to farms. The land allocation criteria are today impossible to apply and remain theoretical, mainly because of the enormous land pressure in the face of the very low rate of development of new areas. The tasks of Office $\mathrm{du}$ Niger are water management and maintenance of facilities. As part of the missions assigned to the ON, the farmers should pay water charges at the end of each crop year.

Eighteen (18) variables are the object of our analysis according to the following multiple regression models:

$\mathrm{Y}=\alpha+\beta_{1} \mathrm{x} 1+\beta_{2} \mathrm{x}_{2}+\ldots+\beta_{18} \mathrm{x}_{18}+\varepsilon$

where $\mathrm{Y}$ indicates family income (representing poverty); $\mathrm{x}_{1}$ represents the age; $\mathrm{x}_{2}$ represents the sex; $x_{3}$ represents marital status; $x_{4}$ denotes means of access to land; $x_{5}$ denotes acreage of parcel allocated; $\mathrm{x}_{6}$ represents mode of access to land; $\mathrm{x}_{7}$ means food problem; $x_{8}$ denotes the level of education of the head of the family farm; $x_{9}$ represents family's education and health support; $x_{10}$ means schooling of children; $x_{11}$ indicates family size; $x_{12}$ denotes water and land management system; $x_{13}$ is another source of income; $x_{14}$ represents water fees; $x_{15}$ stands for drainage problem; $x_{16}$ is about agricultural credit; $\mathrm{x}_{17}$ is production and $\mathrm{x}_{18}$ represents equipment. The income was based solely on the rice that is managed by family farm's head. Equipment was based on tiller, hitch and tractor. Also, $\alpha$ denotes the constant, $\beta 1, \beta 2 \ldots \beta 18$ indicate the respective coefficients of the independent variables whereas $\varepsilon$ is the error term in the model.

\section{RESULTS AND DISCUSSION}

The analysis of the variables indicated a correlation between variable $\mathrm{x}_{18}$ (equipment) and other independent variables when we employ regression model (2) with the cross-section data. According to this model, the independent variables can correlate with the dependent variable Y (income) but cannot correlate with each other. Thus, results suggested that the variable $\mathrm{x}_{5}$ should be excluded from model (2).

\section{Physical capital}

Contrary to our expectations, the area of the allocated parcel is identified as a variable that does not have a significant impact on farmers' incomes. (Sig: 0.30; Table 1). For many farmers, the decrease in farmland is the source of the decline in income resulting in poverty. There is a large dispersion of the parcel allocated by $\mathrm{ON}$ relative to the mean (Mean: 
Table 1 - Summary of statistics of all variables.

\begin{tabular}{|c|c|c|c|c|c|c|}
\hline Variables & Definition & Obs & Mean & Std.dev & Min & $\operatorname{Max}$ \\
\hline Y & Family farm's income & 110 & 6.0545 & 3.59877 & 1 & 10 \\
\hline $\mathrm{X} 1$ & Age & 110 & 3.6000 & 1.03339 & 1 & 5 \\
\hline $\mathrm{X} 2$ & Sex & 110 & 1.0818 & 0.27534 & 1 & 2 \\
\hline $\mathrm{X} 3$ & Marital status & 110 & 2.0545 & 0.42483 & 1 & 4 \\
\hline $\mathrm{X} 4$ & Means of access to land & 110 & 1.6636 & 0.90135 & 1 & 3 \\
\hline X5 & Acreage of parcel allocated & 110 & 2.0364 & 1.28454 & 1 & 8 \\
\hline X6 & Mode of access to land & 110 & 2.1818 & 1.75144 & 1 & 6 \\
\hline $\mathrm{X} 7$ & Food problem & 110 & 1.5727 & 0.49695 & 1 & 2 \\
\hline $\mathrm{X} 8$ & Level of education & 110 & 4.4818 & 2.49672 & 1 & 7 \\
\hline X9 & Family's education and health support & 110 & 1.3273 & 0.47137 & 1 & 2 \\
\hline $\mathrm{X} 10$ & Do your children attend school? & 110 & 1.3273 & 0.52653 & 1 & 3 \\
\hline $\mathrm{X} 11$ & Family size & 110 & 2.8818 & 1.45092 & 1 & 6 \\
\hline $\mathrm{X} 12$ & Water and land management system & 110 & 1.5545 & 0.49929 & 1 & 2 \\
\hline $\mathrm{X} 13$ & Another source of income & 110 & 1.3818 & 0.48806 & 1 & 2 \\
\hline $\mathrm{X} 14$ & Water fees & 110 & 2.7545 & 1.64337 & 1 & 6 \\
\hline $\mathrm{X} 15$ & Drainage problem & 110 & 1.1273 & 0.3348 & 1 & 2 \\
\hline $\mathrm{X} 16$ & Agricultural credit & 110 & 1.8455 & 0.36313 & 1 & 2 \\
\hline $\mathrm{X} 17$ & Equipment problem & 110 & 1.1545 & 0.36313 & 1 & 2 \\
\hline $\mathrm{X} 18$ & Production ( tons) & 110 & 6.1636 & 3.30839 & 1 & 10 \\
\hline
\end{tabular}

2.0364; Std.dev: 1.28454; Table 2). Respondents to questionnaires had an area of 0 to 1.99 ha $(45 \%)$, and 14 ha and more $(1 \%)$. The mode of access to land does not also have a significant impact on income (Sig: 0.40 ; Table 1). There is high dispersion of mode of access to land compared to the mean (Mean=2.1818; Std.dev: 1.75144). The farm permit, the annual operating contract, the renting, the purchase or the sharecropping which are the different modes of access to land, do not have a significant impact on farmer's income. In the village of Dogofiri, $62.7 \%$ of the farmers held the annual operating contract provided by the Office du Niger, 9.1\% held the farm permit, $8.2 \%$ rented the plot, $15.2 \%$ purchased their plot and $4.5 \%$ practiced sharecropping.

The decline in area allocated per family was a goal of rehabilitation programs to promote agricultural intensification (COULIBALY et al., 2006). Population growth with the segmentation of large families led to small farms. Reduction in acreage was part of the ON's policy of intensive rice cultivation. The reduction in area allocated per family was a goal of rehabilitation programs to promote agricultural intensification (COULIBALY et al., 2006). Irrigated land became scarce due to the high demand of land and the fact that the state is not in a position to mobilize the capital necessary for new developments with the lessors (ADAMCZEWSKI et al., 2013a). In fact, the aim of intensive rice cultivation was to increase production and yields. The reduction in land per farmer was not compensated by the increase in production.

The coefficient of the variable production (0.43) is positive and significant, indicating its positive influence on income. A $1 \%$ increase in production increases the income of $0.43 \%$. In fact, if paddy production increases by 0.43 ; income also increases by 0.43 (Table 2). There is a strong dispersion of production in tons compared to the mean (Mean: 6.1636; Std.dev; 3.30839; Table 1). Production varies from one farmer to another. While some farmers produce $5 \mathrm{t} / \mathrm{ha}$, others do not reach $2 \mathrm{t} /$ ha. In short, we fund that the variable of production has a higher contribution to income growth with 
Table 2 - Impacts of determinants on poverty.

\begin{tabular}{|c|c|c|c|c|}
\hline \multirow[t]{2}{*}{ Independent variables } & \multicolumn{2}{|c|}{-------------Coefficient--------------- } & \multirow[t]{2}{*}{$\mathrm{t}$} & \multirow[t]{2}{*}{ P.value } \\
\hline & B & Std. Error & & \\
\hline (Constant) & 1.59 & 3.56 & 0.44 & 0.65 \\
\hline Age & $-0.49 * *$ & 0.25 & -1.98 & 0.05 \\
\hline Sex & 1.23 & 1.25 & 0.98 & 0.32 \\
\hline Marital status & -0.11 & 0.83 & -0.14 & 0.88 \\
\hline Means of access to land & -0.78 & 1.09 & -0.72 & 0.47 \\
\hline Acreage of parcel allocated & -0.39 & 0.37 & -1.04 & 0.30 \\
\hline Mode of access to land & 0.48 & 0.57 & 0.84 & 0.40 \\
\hline Food problem & -0.02 & 0.60 & -0.04 & 0.96 \\
\hline Level of education & 0.06 & 0.09 & 0.66 & 0.51 \\
\hline Family's education and health support & $-1.13^{* *}$ & 0.62 & -1.81 & 0.07 \\
\hline Do your children attend school? & 0.25 & 0.50 & 0.50 & 0.61 \\
\hline Family size & $0.38^{* *}$ & 0.21 & 1.73 & 0.08 \\
\hline Water and land management system & 0.18 & 0.50 & 0.36 & 0.71 \\
\hline Another source of income & -0.68 & 0.49 & -1.38 & 0.17 \\
\hline Water fees & $1.09^{* * *}$ & 0.40 & 2.71 & 0.00 \\
\hline Drainage problem & -0.32 & 0.64 & -0.50 & 0.61 \\
\hline Agricultural credit & $1.40^{*}$ & 0.85 & 1.64 & 0.10 \\
\hline Production (tons) & $0.43^{* * *}$ & 0.15 & 2.84 & 0.00 \\
\hline
\end{tabular}

Note: Dependent variable: Annual income; ${ }^{* * *}$ means coefficient significant at $1 \%$ level of significance; ${ }^{* *}$ significant at $5 \%$ and ${ }^{*}$ significant at $10 \%$.

a coefficient of 0.43 . The real data collected from the villager Association (AV) of Dogofiri, a legal structure about management of paddy production, indicated low production. The production concerns 219.33 ha that AV manages with a total of 329.50 ha for the whole village. Production is often dependent on climatic hazards. The bad crop year 2003 was marked by heavy rains, lack of inputs, and diseases (COULIBALY et al., 2006). The lowest production of the village recorded during the 2007-2008 crop year with a total production of 734.940 tons and a yield of 2.2 tons of paddy per hectare (Table 3 ). According to the farmers, the lower production was related to the fact that the $\mathrm{AV}$ in charge of supplying the whole village with fertilizer did not have any suppliers because of the arrears of unpaid fertilizer credits. Only affluent peasants were able to pay cash for fertilizer. Fields of those who did not have the financial means to pay cash the fertilizer did not got fertilizer while its application is required to increase production and yield because soils are poor. In 2008 , the price of the bag of $50 \mathrm{~kg}$ of fertilizer rose from $17,500 \mathrm{CFA}$ to $18,000 \mathrm{CFA}$, too expensive for a farmer who has trouble doing feed. The low yield of 2018 was because of the lack of irrigation water since the beginning of the crop operations. In addition, the difficulties associated with the supply of fertilizer have resulted in farmers not receiving the normal quota according to the area they own. In fact, the lack of irrigation water during ripening of the grain or insect attack are the main causes of rice husk or empty seeds during the harvest causing the decrease of the yield. Problem of access to agricultural inputs is still topical in ON causing bad production (BELIERE et al., 2011). According to BOLY, General Secretary of Farmer's Union in ON (Sexagon), managers did not tell the truth about the production. For several years, producers shared their concerns about the decline in yields. In their farm, they obtained 2.6 tons per hectare, while official data from ON were 6 tons. The 
Table 3 - Evolution of paddy production from 2005 to 2018 of Dogofiri.

\begin{tabular}{|ccc|}
\hline Crop years & $\begin{array}{c}\text { Paddy production } \\
\text { in tons }\end{array}$ & $\begin{array}{c}\text { Paddy yield in tons } \\
\text { per hectare }\end{array}$ \\
\hline $2005-2006$ & $1,469.880$ & 4.5 \\
\hline $2006-2007$ & $1,347.39$ & 4.1 \\
\hline $2007-2008$ & 734.940 & 2.2 \\
\hline $2008-2009$ & 808.434 & 2.4 \\
\hline $2009-2010$ & 857.43 & 2.6 \\
\hline $2010-2011$ & 288.75 & 4.3 \\
\hline $2011-2012$ & 270 & 3.8 \\
\hline $2012-2013$ & 304.3 & 4.1 \\
\hline $2013-2014$ & 327.3 & 4.2 \\
\hline $2014-2015$ & 1014.375 & 4.8 \\
\hline $2015-2016$ & 1036.35 & 4.7 \\
\hline $2016-2017$ & 987 & 4.5 \\
\hline $2017-2018$ & 822.525 & 3.7 \\
\hline
\end{tabular}

Source: Dogofiri villager Association (2018- 2019).

production target should have been 1,000,000 tons, but we are at about 730,000 tons (Dr COULIBALY, CEO of $\mathrm{ON}$ ).

Following food crises, including that of 2008, the Government of Mali launched the "Rice Initiative". This project aimed to cover the needs of internal consumption and pushing Mali into a potential rice- exporting country. "The Rice Initiative", set the price of $50 \mathrm{~kg}$ fertilizer bag at 12,500 CFA for farmers. Nowadays, with "Rice Initiative", the bag of $50 \mathrm{~kg}$ of fertilizer is sold at 11,500 CFA. At the end of 2008-2009 crop years, the Government announced a record paddy production of 1,607,000 tons. Despite these efforts, the price of rice does not drop in the markets (ROY, 2010). The Rice Initiative has not produced the expected result.

Agricultural credit has a significant impact on family farm income. A $1 \%$ increase in agricultural credit increases income by $1.40 \%$. (Table 2 ). There is a high dispersion of access to agricultural credit (Mean: 1.8455; Std.dev: 0.36313; Table 1). Farmers do not have similar access agricultural credit.

Microcredit is defined as supply of financial services to poor people excluded from banking system. Microcredit can help them to lead productive and income-generating activities in order to improve their living conditions. Financial institutions which finance farmers in Dogofiri are Bank of agriculture $(B N D A)$,
Nyessiguisso and Kafo djiguigne. The demanding conditions of microcredits are impoverishment for farmers in $\mathrm{ON}$ zone. In Dogofiri, microcredit services have specificity to recover their credits rigorously than previously with a rate of recovery of credits that reaches $95 \%$. The granting of new credit is subject to provision of an individual guarantee of 10 to $20 \%$ of credit amount and repayment of previous credit (KUPER et al., 2002). Material guarantee fees and personal contributions requested very high with often deposits required in the case of individual credit of Nyessiguisso microcredit. The Nyessiguisso required a deposit of $10 \%$ guarantee with a high annual interest rate $(16 \%)$. The same practices are observed in some Asian countries. RASHIDIN et al. (2017) reported that in Pakistan many respondents complained about the very high interest rate of micro-finance and personal guarantee as the main difficulty to obtain loan. With a slightly lower interest rate, Kafo djiguigne has almost the same conditions. A co-operative does not obtained credit from Kafo djiguigne if one of its members is heavily indebted. Despite the low interest rate $(10 \%)$ of Agricultural Bank (BNDA), farmers prefer microfinance. Farmers were victims of rip off related to $B N D A$ credits. Agricultural credit allowed farmers to pay for agricultural inputs in order to increase their production and income. The behavior of some farmers after reception loan (negligence or misuse of the purpose of loan) explains poverty. In small farms, part of the loan (money in cash) is transferred to self-consumption, such as purchase of food and medical prescriptions. Generally loans coincide with lean period during which most of farmers don't have financial means to deal with rice cultivation. Fields no longer received normal agricultural input. This leads to low yield and poverty. Rather, they are oriented towards the meeting of basic needs, especially food during the lean season (KONE et al., 2004). It was reported that in developing countries, farmers use credit for other purposes at the expense of agricultural needs, and this may lead them to neglect certain elements of management of their rice plots (COULIBALY et al., 2017). Lack of access to credit has developed the informal credit system. This is the loan on terms laid down at two people. Wealthy farmers and village traders grant loans to poor farmers which are repaid by $75 \mathrm{~kg}$ of paddy exchange for 7,500 CFA. The credit of one ton of paddy costs 80,000 CFA. These loans are paid back immediately after harvest. The reimbursement often leads to a conflict between the contracting parties. Some farmers are dispossessed of almost all their production after the repayment of the credits.

Ciência Rural, v.50, n.2, 2020. 
In Office du Niger, production apparatus includes tillage tools and animals that make up the labor force. Material consists of plows, harrows, carts, traditional tools (sickles, picks, axes, hoes, $d a b a$ ) etc. Draught animals are oxen. Donkeys are mostly used to pull carts, main mode of transport for farmers and products. There are few farmers who use tiller and tractor. Agricultural equipment is much dispersed compared to the mean (Mean: 1.1545; Std. dev: 0.36313; Table 1). Many farmers do not have equipment to develop the land. Family farms using a single plow represented $52.5 \%$. Those using 2 plows represented $2.5 \%$. Farmers who don't have harrow in their exploitation represented $50 \%$. Farms with two harrows represented only $2.5 \%$. Farms with no tillers were $75 \%$. Farms using two tillers or more represented $2.5 \%$. The large majority of farms, $70 \%$, do not have oxen. No family farm possesses a tractor. Lack of equipment causes considerable delay for the performance of agricultural work. All farming activities should be performed on time. Lack of equipment led to the non-respect of agricultural calendar and decrease production. In Dogofiri, 47, $5 \%$ of respondents fail to respect agricultural calendar due to lack of equipment.

\section{Human capital}

In terms of human capital, some sociodemographic characteristics such as the ages of respondents, health care and education as well as family size have a significant impact on farmers " incomes. In this study, the age of the respondents is slightly dispersed compared to the mean (Mean: 3.6000; Std.dev: 1.03339; Table 1). Most of the head of family farm are adults. The negative coefficient of the age suggested that income will increase if the farmer is young. As a result, if the age increases by 0.49 ; income decreases by 0.49 , that means income decreases with age (Table 2). Indeed, in the village of Dogofiri, according to tradition and culture, the head of the family farm who is the oldest decides the management. Many of them who did not attend school do not manage well the farm and cannot be criticized. Many farm managers do not listen to their subordinates. According to Ongoiba M, farmers responsible for supervision in Dogofiri, young people no longer work. They left farming activities because of disappointment. In fact, many heads of family farms monopolize production without worrying about young people and women whose share is limited to food and who have to take care of themselves. Farm incomes are concentrated in the hands of head of family farm which monopolizes without share reasonably with family dependent (BELIERES et al., 2002). In most cases their decisions impact income. This departure of young people has led to a real labor problem in the area.

Our results indicated that health care and education have a significant impact on income. The negative coefficient suggested that the health and education of the family farms improve if members have access to health facilities and education (Table 2). Many families have difficulties in caring for the education and health care of their members (Mean: 1.3273; Std.dev: 0.47137; Table 1). Dogofiri health center staff includes a physician, a senior health technician and a nurse for a population of 28,000 inhabitants. Water-related diseases are the most common and concern malaria, diarrhea and urinary bilharzia. For their treatment, the population prefers traditional medicine, Pharmacie par terre "Pharmacy on the ground" and itinerant treating because conventional medicine is costly. These medicines are very poorly preserved and cause real health problems in the area.

According to DEM, literacy trainer, in 1978, the officials of the Office du Niger were not interested in training farmers. They were more concerned about rice production. The Netherlands, as part of its agricultural cooperation with Mali, has been demanding the literacy of the farmers. Today, even if there is a basic school in Dogofiri, many heads of families are not interested in school because of its cost but also and above all children are a labor to keep them at home for farming activities. The rate was $43 \%$ of heads family farm who did not have any basic training in the ON zone (KEBE et al., 2005). Farmers often voluntarily terminate the schooling of their children so that they can help in farming activities. Many children drop out of primary school because of their parents. The respondents who attended the university are native of village and practice farming while waiting for paid employment. Level of education is very important in the production and management process. With no improving education levels, equitable sustained economic growth will not occur (HARBER, 2002). In Uganda, findings showed performance of farmers who attended primary school (HERFKENS, 2002). With 4 years of school, Uganda farmers produced $7 \%$ more than those who did not attend school. Access to information allows farmers to increase their production and improve their incomes (FIGUERE, 2014).

Family size impact the income. Most of the families are of large size slightly dispersed compared to the mean (Mean: 2.8818; Std.dev: 
1.45092; Table 1). Results indicated that the increase of family of one person leads to an increase in income of $0.38 \%$ (Table 2 ). Indeed, the number of person would be an asset if everyone is involved in farming activities. Unfortunately, in Dogofiri, young people who are active workforce are increasingly refusing rural activities. The study reported that gender and marital status do not have a significant impact on income. In that case, the Office du Niger has to take into account the gender for the allocation of farm plots.

The Office du Niger lacks human resources for farmer's guidance. There is a lack of rural adviser whose role is to popularize new technologies and teach farmers how to manage their income. The supervisory staff of the farmers is not enough. ONGOIBA, rural adviser in Dogofiri, takes care of 24 villages. According to ONGOIBA, when a farmer misses a popularization demonstration, he has a limited chance to participate again.

\section{Technology}

In that regard, the use of inputs, drainage and rice processing are mentioned by farmers as a cause of poverty. There is a low dispersion of the drainage problem compared to the mean (Mean: 1.1273; Std.dev: 0.3348; Table 1). Contrary to our expectations, linear regression analysis indicated that drainage does not have a significant impact on farmers' income (Table 2). However, during our surveys, the farmers mentioned a real problem related to poor drainage. The problem of drainage at the level of the tertiary canal created serious problems in the management of water in the plots. This problem caused a lot of water loss that affect access routes and caused production losses during harvest. The irrigation system is confronted with perpetual drainage problems during harvest, resulting in high production costs as well as loss of production and/ or quality (VANDERSYPEN, 2007). Farmers do not respect the cleaning obligations of the tertiary canal and related water management tasks (SOUMANO $\&$ TRAORE, 2017). The malfunctioning of the irrigation system seems to be the factor contributing to soil degradation in Mali that is very closely link to poor drainage conditions and low water efficiency (BAGAYOKO et al., 2007). Poor drainage and intensive use of chemical fertilizers to increase production are problematic. In a number of irrigated areas of $\mathrm{ON}$, indications of soil degradation due to salinization, alkalinity and sodification were seen. Survey data showed that $20 \%$ to $50 \%$ of cultivated soils with vegetables were affected by salinization and alkalinity (BAGAYOKO et al., 2007). Alkalization and sodisation impact yields of paddy per hectare.

The development of rice technologies, generated by the irrigated rice program, has been influenced by the change in the rice growing system. In 1985, the evolution of the cropping system from the extensive to the intensive began in the ON with the start of the project "Retail" oriented towards the intensification of the double cultivation of rice. This project involved Niono production zone with introduction of transplanting and the first shortstraw, medium-cycle (120-145-days) and early (110125-days) varieties from sowing to maturity. These technologies have a production potential of 10 tons/ ha with an average yield of between 5 and 6 tons. Among all the technologies developed in intensive system in irrigated rice growing zones for crop season, the variety Kogoni 91-1, commonly called by the producers "Gambiaka Suruni", is the most widely field - grown rice variety.

The rice milling factory of Dogofiri built by the People's Republic of China in 1966 and employed nearly 2000 permanent or temporary workers is bankrupt (Figure 2). The bankruptcy of the factory has left unemployed workers who were forced to seek land to cultivate or convert to a farm worker. Rice milling bankruptcy and the termination of employment is one of the causes of poverty in Dogofiri. Farmers use the less efficient small rice husking machines imported from China. Bankruptcy has a definite impact on the quality of the rice and the way it is packaged.

\section{Government policy}

Office du Niger is public establishment with industrial and commercial character restructured in 1994. Farmers access land and water through an annual operating contract or a farm permit, which submit them to a specification stating that the parcel cannot be rented or mortgaged; failure to comply with these rules may lead to the eviction of the farmer (ADAMCZEWSKI et al., 2013b). The large reduction in the irrigated area cultivated by family farm was not compensated by the increase in yields. Inequalities between farms tend to worsen and some small farms enter a circle of poverty that can lead them to pledge their land, or to be evicted by the Office du Niger to irrigated land because they are unable to pay their water fees (DROY \& MORAND, 2013). The new policy of the Malian Government since the restructuring of the Office of Niger has refocused the missions of $\mathrm{ON}$ to water management and maintenance of the facilities. This restructuring 


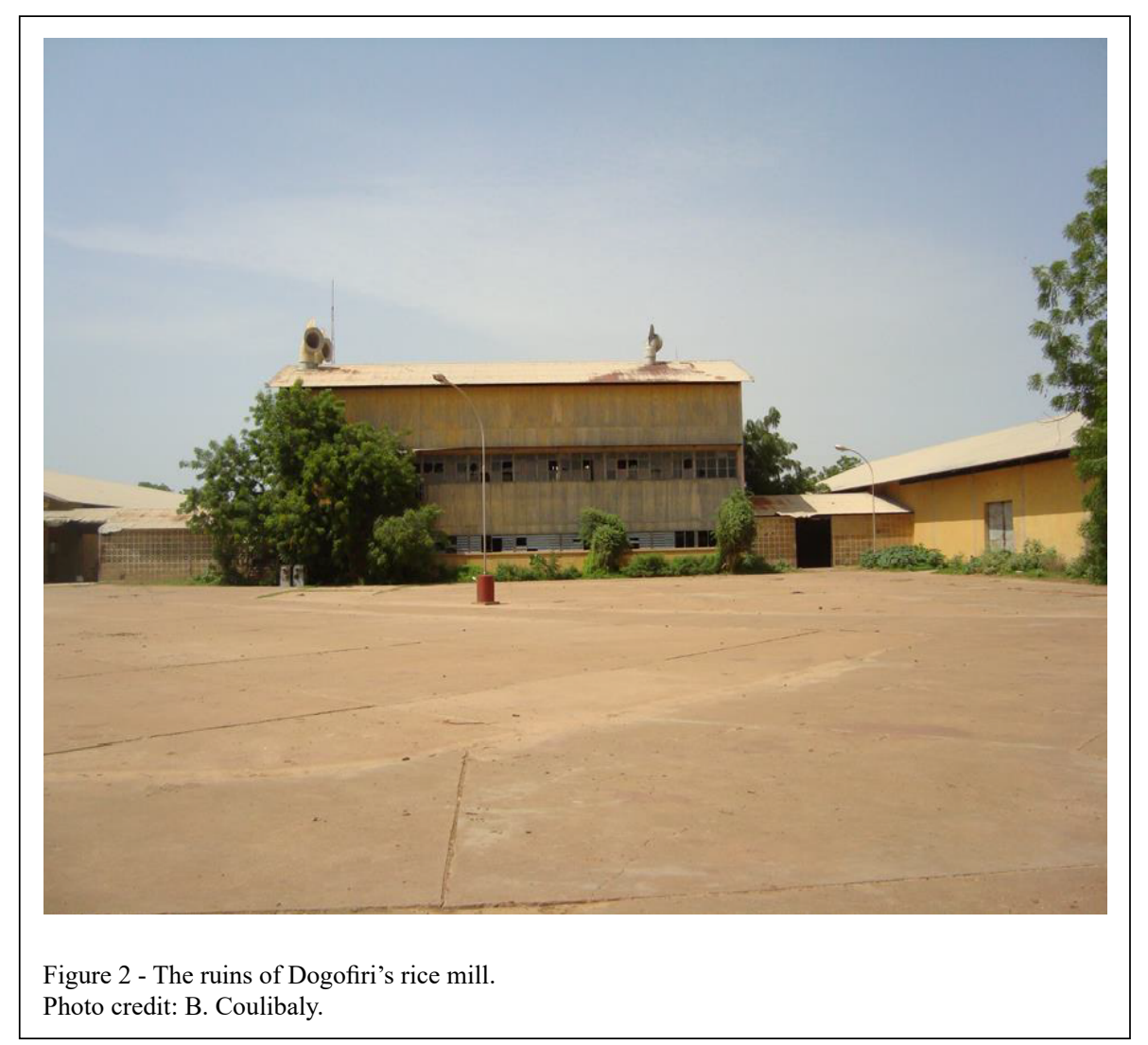

aimed greater liberalization of the economy and a transfer of responsibility from the State to private actors. It is within this mission that $\mathrm{ON}$ is responsible for the recovery of water fees. Water fees are highly dispersed relative to the mean (Mean: 2.7545; Std. dev: 1.64337; Table 1 ). The payment of the water fee is relative to the number of hectares the farmer owns. water fees coefficient (1.09) is positive and significant, indicating its positive influence on income. A $1 \%$ increase in water fees increases income by $1.09 \%$ (Table 2). The increase in water fees would mean improving the quality of water management for high productivity. Before, water charges were a fixed levy of $400 \mathrm{~kg}$ of paddy per hectare. Currently, water fees are set at 56,950 CFA. This is still high for farmers living in precarious conditions. The rule in force is that any tenant who wouldn't pay the full fees for the use of water; calculated on the basis of the water requirements for rice per hectare allocated; would lose access to the entire area (SOUMANO \& TRAORE, 2017). Farmers often prefer to pay for consumer goods such as two-wheeled gear and waste of their hard- won earnings instead of paying their water fees. To avoid the eviction linked to the non-payment of the water fees, farmers carry out practices prohibited by ON like the lease or sale of a portion of the parcel allocated (COULIBALY et al., 2006). Family farms have adapted by developing strategies for appropriation, including an illegal land market (COULIBALY\& BELIERE, 2006). Increasingly, farmers are adopting other irrigated land management practices such as subletting and selling which are official practices as they are known to everyone, but clandestine under the law that legally prohibited it (ADAMCZEWSKI et al., 2013a). In ON, during 2014-2015 crop years, evictions concerned 1592.54 ha for an amount of 83,203,281CFA (ON). Eviction increases landless and poverty. Improvement of water management is; therefore, a major challenge for the coming years, with the objectives of ensuring the sustainability of infrastructure, saving resources, reducing service costs and ensuring the quality of water (KEITA et al., 2001).

To support farmers, the government adopted a new policy in 2008. Following food crises, 
including that of 2008, the Government of Mali launched the "Rice Initiative". This project aimed to cover the needs of internal consumption and make Mali a potential exporting country of rice. "The Rice Initiative", set the price of $50 \mathrm{~kg}$ fertilizer bag at 12,500 CFA for farmers. Nowadays, with "Rice Initiative", the bag of $50 \mathrm{~kg}$ of fertilizer is sold at 11,500 CFA. At the end of 2008-2009 crop years, the Government announced a record paddy production of $1,607,000$ tons. Despite these efforts, the price of rice does not drop in the markets (ROY, 2010). The Rice Initiative has not produced the expected result. In fact, practices of small head farm were to acquire the fertilizer from the "Rice Initiative" and sell it at a lower price in order to pay food. Some farmers, because of insufficient funding, sell part of the fertilizer got in credit to pay for rice transplantation that requires the payment of the labor. Farmers should pay the fertilizer back at the end of the crop year. In this case, the fertilizer offered did not reach its objective. Indeed, the "Rice Initiative" offers fertilizer during the welding period where some farmers especially those with small farms had food problems. In that case, the rice paddy fields did not receive the recommended fertilizer per hectare. The amount recommended of fertilizer for phosphate is $100 \mathrm{~kg} / \mathrm{ha}$ and the amount of urea varies between 150 and $200 \mathrm{~kg} / \mathrm{ha}$ (AUDIBERT, 1997). Failure to respect timely fertilizer use is also at the origin of rice husk during harvest.

Agricultural development slightly increase because of its very expensive. Population growth and affluence in the Office du Niger zone have led to significant land pressure. Family farms are confronted with a difficult environment, particularly in terms of land policies, in a context of increasing merchandising of land that promotes private property (BRONDEAU, 2019). Irrigated land became scarce due to the high demand of land and the fact that the state is not in a position to mobilize the capital necessary for new developments with the lessors (ADAMCZEWSKI et al., 2013a). The ON had to play a key role in food security and poverty reduction. Aware of the high demand for land for rice cultivation in the area and the important role of irrigated agriculture in poverty reduction, the Government of Mali launched a large project at the end of the year 2008. This project, called the Millennium Challenge Account-Mali, comprises two major components in the Office zone. A road component which was about $81 \mathrm{~km}$ connecting the city of Niono to the Village of Goma Coura and a development component was 16,000 ha in the perimeter of Alatona in the area of Kouroumari in the sub-prefecture of Sokolo. According to the person in charge of the implementation of the development component, Alatona irrigation project due to its harmonious and sustainable integrated development, aimed to increase production and productivity through land improvement, modernization of irrigated production systems, mitigation of uncertainties in subsistence farming dependent on climatic hazards; and therefore, the increase in farmers ' incomes (Les Echos, 2008). The aim was also to promote mediumsized private enterprises (10 to $50 \mathrm{ha}$ ), able to finance part of the hydraulic facilities and to participate in the increase of paddy production. In compensation, these companies got land titles (BRONDEAU, 2013). The project delayed by insecurity in the area, solved part of the problem that still remains because of the influx in the area and the population growth.

\section{Poverty situation}

The ignorance of poverty determinants led, inter alia, to the ineffectiveness of Government policy to combat poverty, especially in rural areas. In Mali, the poverty line was set at 177,000 CFA in 2015 (INSTAT, 2015). Anyone who cannot afford to spend 177,000 CFA needed to meet basic needs is considered poor. In the village of Dogofiri, family farm incomes are highly dispersed relative to the mean (Mean: 6.0545; Std.dev: 3.59877; Table 1 ). The income of farmers in ON declined despite the important role of ON in Malian economy and food security (SOUMANO \& TRAORE, 2017). If family farms generated low incomes, those with migrants faring better (SOURISSEAU et al., 2012).The low income level led to poverty perceived in different ways in the village and throughout the ON zone. According to the RuralStruc survey (SAMAKE et al., 2008), the median and mean household incomes in the Office du Niger area are higher than those of other rural areas in Mali. But this mean (101,000 CFA per capita/year in 2007 or $€ 153$ ) remains below the national poverty line, which relativaze the "wealth" of the area (DROY \& MORAND, 2013). Poverty is a complex and multifaceted phenomenon that requires clear analysis in all its aspects. Human beings are profoundly diverse so; we can not draw a poverty line and then apply it to all in the same manner, without considering personal characteristics and circumstances (SEN, 1983).

In general, our respondents defined poverty as food non-self-sufficiency or food insecurity, lack of land, lack of equipment and insufficient income. Poverty is defined by words in the national language Bambara (Fantanya, Dese Baga Toya) that characterize a lack of food, land, equipment 
or income (BELIERESJ et al., 2011). The wealthy farmers are those who manage to support their own family's needs and able to support other people. Intermediaries are those who are self-sufficient but cannot help others while the poor cannot provide for the family (BELIERESJ et al., 2011). For that purpose, the causes of poverty are often confused with the definition. In the Office du Niger zone, some farmers are facing food problems. Our results indicated that the food problem is poorly dispersed compared to the mean (Mean: 1.5727; Std.dev: 0.49695; Table 1). Farmers whose rice production can support them in food throughout the year represent $50.9 \%$ of our respondents. $9.1 \%$ of farmers had rice that covers their food needs between 6 and 8 months. Indeed, after the harvest many farmers manage poorly their production. Into the minds of many farmers, each crop year must be crowned by the purchase of a new motorbike and that at any price. Few farmers invest in the means of production. Thus, $40.2 \%$ of respondents had food problems during the welding period in July and August. Indeed, it is the poor who lacks food. Accordind to (SEN, 1983), those living in poverty cannot afford to get the type of diet, participate in activities and benefit from the usual living conditions and facilities. During the weld, expensive paid motorcycles were sold at very low price either to pay for food or to pay inputs. The period of welding is delicate, the attics being empty for two to six months (SOURISSEAU, 2000). During the welding, some farmers take credit called in language Bamanan "boro juru" or "toni juru": credit of $75 \mathrm{~kg}$ paddy and credit of one ton of paddy. The first is reimbursed at 5,000 CFA and the second 80,000 CFA. The repayment of these credits dispossesses almost some farmers of their production.

The school attendance rate of children is high (Mean: 1.3273; Std.dev: 0.52653; Table 1 ). Many heads of family farm did not attend school. There is a large dispersion of the level of education compared to the mean (Mean: 4.4818 ; Std.dev: 2.49672; Table 1). There was a rate of $43 \%$ of heads family farm who did not have any basic training in the ON zone (KEBE et al., 2005). Farmers often voluntarily terminate the schooling of their children so that they can help in farming activities. Many children drop out of primary school because their parents cannot afford to pay for their studies. Some parents who are hostile to school refuse to have their children especially girls attending school. As $70 \%$ of children attended school, there are few who would be able to continue their education at the secondary level. The respondents who attended the university are native of village and practice farming while waiting for paid employment. The level of education is very important in the production and management process. With no improving education levels, equitable sustained economic growth will not occur (HARBERT, 2010).

Despite some progress, health facilities are lacking in Dogofiri. Access to health services remains difficult for some communities. For example, the village of Farabougou, which is part of the rural municipality of Dogofiri, is located $15 \mathrm{~km}$ from Dogofiri health center. The longest distances (4 to 35 $\mathrm{km})$ from a village to the nearest health centers are mainly observed in Kouroumari, of which Dogofiri is a part (KEBE et al., 2005). $67.3 \%$ of our respondents reported being able to take care of their family's health and education needs. Populations feel that prescription fees are too high; therefore, preferred to pay for unsecured, open-sourced drugs and traditional medicines. These medicines in the majority of cases create health problems for those who consume it. These medicines called "Medicaments par Terre" (medicines on the ground), are sold in shops, at the market and at home without any condition of conservation.

\section{CONCLUSION}

Our research aimed to analyze the determinants of poverty of rice farmers in the village of Dogofiri in ON and to show the priority axes on which the actors should focus in order to succeed the poverty alleviation policy. Our results showed that the water fees considered excessive by farmers have a significant impact on farm income. It is the same as the decline in production. The agricultural growth generated by family farms should not hide the poverty that is becoming endemic in the village. Our results showed that the many farmers were fighting to ensure basic needs. This struggle for survival is at the origin of an illegal land market that is growing more and more. Along with this illegal market, farmers created a new credit system to get around microcredit and banks that require complicated procedures for them. All these practices aggravate the farmer's poverty. For this purpose, there is a need to review farmers' supply mechanism for agricultural inputs through the Rice Initiative. Market gardening became after rice production, the activity which is carry out mainly by young people and women in order to solve their own needs.

Faced with the inability of family farms to ensure food self-sufficiency, the Malian government has launched an appeal for foreign investment to develop and modernize its agriculture in $\mathrm{ON}$. The 
aim of this foreign investment policy is to modernize agriculture and to ensure the country's security and food sovereignty. These foreign investments, including Malibya investment, resulted in the displacement of some villages and prevented the gardening and rainy culture of millet. This created more problems than it solves. In addition, the government through the policy of the rice initiative continues to subsidize agricultural inputs especially fertilizer offered to farmers.

In the light of these results, we suggested certain policy implications with regard to alleviate poverty in the Office du Niger zone. Family farms in ON have ability to get out of poverty if they are funded. But it is necessary to adapt agricultural investments to the capacities of these types of farms. The authorities responsible for the development of rice cultivation must create financing structures for low-interest rate in order to allow the massive access of farmers. ON must establish literacy centers to train farmers in the use of new technologies and management concepts. The innovations should concern fish farming, tubers and livestock. These innovations will be new sources to improve farmers ' incomes. Dogofiri rice mill must be operational in order to process high quality rice that can be exported and create jobs in the village. The state should be involved in monitoring all activities. Further studies are needed in different rice production areas in order to identify all the determinants of poverty, which could be used by policymakers.

\section{ACKNOWLEDGEMENTS}

We thank China University of Geosciences and University of Ségou in Mali. This research was funded by [the National Social Science foundation of China] grant number [No.16BJY049], and [the Special Fund for Basic Scientific Research of Central Colleges, China University of Geosciences (Wuhan) ] grant number [No.CUG170105].

\section{DECLARATION OF CONFLICT OF INTERESTS}

The authors declare no conflict of interest. The founding sponsors had no role in the design of the study; in the collection, analyses, or interpretation of data; in the writing of the manuscript, and in the decision to publish the results.

\section{AUTHORS' CONTRIBUTIONS}

Brahima Coulibaly wrote the original draft preparation. The second author Shixiang $\mathrm{Li}$, as the corresponding author, propose the topic, guideline the writing and correct the draft. The third author Zhanqi Wang offer some suggestions and resources.

\section{REFERENCES}

ADAMCZEWSKI A.et al. Concessions de terres et dynamiques sociales dans la zone Office du Niger au Mali. p.37-61, 2013a. Available from $:<$ http://etudesrurales.revues.org/9762>. Accessed: Feb. 02, 2019.

ADAMCZEWSKI A. et al. Terre, eau et capitaux: Investissements ou accaparements fonciers à l'Office du Niger ? Cah Agric, 22 : 22-32, 2013b. doi: 10.1684/agr.2012.0601.

SEN, A. What poverty is? p.43, 1983. Available from: <https:// thl.fi/documents/189940/263914/FFF3C_3.pdf>.

AUDIBERT M. Technical inefficiency effects among paddy farmers in the villages of the 'Office du Niger', Mali, West Africa. Journal of Productivity Analysis, 8, n.4, p.379, 1997. Available from: <https://doi.org/10.1023/A:1007767508848>. Accessed: Feb. 02, 2019.

BAGAYOKO M.et al. Characterisation of soil degradation under intensive rice production in Office du Niger zone of Mali. Springer Netherlands, p.133-138, 2007. doi: 10.1007/978-1_11.

BAGGIO C.A.; KHUL M.R. Determinants in value appropriation in smallholder farming innovation. Ciência Rural, v.48:03 e 2017 0297, p.9, 2018. Available from: <http://dx.doi.org/10.1590/01038478cr20170291>. Accessed: Feb. 02, 2019.

BELIERE J.F. et al. Irrigation et pauvreté : le cas de l'Office du Niger au Mali. Cahiers Agricultures, 20 (n. 1-2): 144-9, 2011. doi: 10.1684/agr.2011.0473.

BRONDEAU F. Confrontation de systèmes agricoles inconciliables dans le delta intérieur du Niger au Mali? p.1935, 2013. Available from: <http://etudesrurales.revues.org/9748>. Accessed: Feb. 02, 2019.

BRONDEAU F. The Office du Niger: an Agropole project for food security in Mali? Cybergeo : European Journal of Geography, [En ligne], Espace, Société, Territoire, document 870, mis en ligne le 08 novembre 2018, consulté le 25 mars 2019. Available from: $<$ http://journals.openedition.org/cybergeo/29606>. doi: 10.4000/ cybergeo.29606. Accessed: Feb. 02, 2019.

COULIBALY A. et al. Les déterminants de l'efficience technique des riziculteurs de l'Office du Niger au Mali. Journal of Agriculture and Environmental Sciences, v.6, n.2, p.88-97, 2017. Available from: <https://doi.org/10.15640/jaes.v6n2a9>. doi: 10.15640/jaes.v6n2a9. Accessed: Feb. 02, 2019.

COULIBALY Y. et al. Les exploitations agricoles familiales du grand périmètre irrigué de l'Office du Niger au Mali : évolutions et perspectives. Cahiers Agricultures, v.15, n.6: 562-569, p.8, 2006.Available from: <https://revues.cirad.fr/index.php/cahiersagricultures/article/view/30618>. Accessed: Feb. 02, 2019. doi: 10.1684/agr.2006.0024.

COULIBALY Y.M.; BELIERE J.F. Contrainte foncière et stratégie d'appropriation par les exploitations agricoles du grand périmètre irrigué de l'Office du Niger au Mali. p.13, 2006. Available from: <https://agritrop.cirad.fr/>. Accessed: Feb. 02, 2019.

DIBBA L.et al. The impact of NERICA adoption on productivity and poverty of the small- scale rice farmers in Gambia. p.13, 
2012. Available from: <https://link.springer.com/article/10.1007/ s12571-012-0180-5>. Accessed: Feb. 02, 2019. doi: 10.1007/ s12571-012-0180-5.

DOUMBIA D. et al. Livestock in the rice-based economy of Office du Niger: The development potential for increased croplivestock integration through multi-actor processes. Journal of Life Sciences, v. 60-63, p.101-114, 2012. Available from: $<$ https:// doi.org/10.1016/j.njas.2012.07.002>. Accessed: Feb. 02, 2019.

DROY I.; MORAND P. Les grands aménagements sur le fleuve Niger: Atout pour le Mali ou facteur de vulnérabilité pour ses populations rurales? Monde en Développement, n.164, p.57-70, 2013. Available from: <https://www.cairn.info/revue-mondes-endeveloppement-2013-4-page-57.htm>. Accessed: Feb. 02, 2019.

FIGUERE C.M.; EUGELINK H. The role of ICTs in poverty eradication: More than 15 years' experience from the field. Springer Science Business Media New York, Chapter 12, 24, 2014. Available from: <https://doi.org/10.1007/978-1-4899-7439-6_12>.

HERFKENS E. L. Accelerating action towards education for all: Reducing poverty through basic education. 2002.

INSTAT-INSTITUT NATIONAL DE LA STATISTIIQUE DU MALI. Consommation, pauvreté, bien être des ménages: Enquête modulaire et permanente auprès des ménages (EMOP). p.102, 2015. Available from: <http://www.instat-mali.org/contenu/eq/ ranuel15_eq.pdf $>$. Accessed: Feb. 02, 2019.

KEBE D. et al. Evaluation de la pauvreté en zone Office du Niger. Rapport final, IER Bamako, p.96, 2005. Available from: <https:// agritrop.cirad. fr/543524/1/document 543524pdf $>$. Accessed: Feb. 02, 2019.

KEITA I. et al. Gestion du système hydraulique de l'Office du Niger: évolutions récentes et perspectives. p.65-81, 2001.

KONE Y. et al. L'endettement, une contrainte à l'accès au crédit ? Cas des exploitations familiales de la zone irriguée de l'ON, au Mali. p.6, 2004.

KUPER M. et al. L'Office du Niger, grenier à riz du Mali: succès économiques, transitions culturelles et politiques de développement. Montpellier, France: CIRAD, Karthala, 2002.

MATHER D.; KELLY V. Farmers' Production and Marketing Response to Rice Price Increases and Fertilizer Subsidies in the Office du Niger. MSU International Development Working Paper 129, p.103, 2012. Available from : $<$ http://ageconsearch. umn.edu/record/Files/idwp129.pdf $>$. Accessed: Feb. 02, 2019.

OYINBO O.; OLALEYE K.T. Farm households livelihood diversification and poverty alleviation in Giwa local government area of Kaduna State, Nigeria. The Journal of Sustainable
Development, v.15, Iss.1, p.219-232, 2016. Available from: $<$ https//doi.org/107916/D8GH9HSG>. Accessed: Feb. 02, 2019.

RASHIDIN Md.S. et al. An empirical study on determining the association between micro finance and poor's access: Evidence from Pakistan. Sonargaon University (SU) Journal, v.2, p.16-31, 2017.

ROY A. L'initiative riz au Mali: une réponse politique à l'insécurité alimentaire? Editions Karthala, n.119, p. 87-105, 2010. Available from: $<$ https://www.cairn.info/revue-politique-africaine2010-3-page-87.htm>. Accessed: Feb. 02, 2019.

SAMAKEA. et al. Changements structurels des économies rurales dans la mondialisation Programme RuralStruc Mali - Phase II. IER/CIRAD/MSU Banque Mondiale/Coopération française /FIDA, p.464, 2008. Available from: <http://siteresources.worldbank.org/ AFRICAEXT/Resources/RURALSTRUC-MALI_Phase2.pdf>. Accessed: Feb. 02, 2019.

SAVARD J. G. Statistiques. Montréal. Les Editions HRW, p.133138 et $171-176,1978$.

SOUMANO L.; TRAORE M. Contribution of an innovation platform to change the management of collective irrigation: a case study from the Office du Niger (Mali). Cahiers Agricultures. p.7, 2017. doi:10.1051/cagri/2017030.

SOURISSEAU J.M. Les stratégies de diversification des revenus sur les grands aménagements hydro-agricoles Sahéliens, Les cas de L'Office du Niger au Mali et du delta du fleuve Sénégal. s.1: Université de Paris-Nanterre. Thèse de doctorat : Economie : Université de Paris-Nanterre, p.668, 2000.

SOURISSEAU J.M. et al. Les modèles familiaux de production agricole en question. Comprendre leur diversité et leur fonctionnement. Presses de Sciences Po (P.F.N.S.P.), n.62, p.159-181, 2012. Available from: <https://www.cairn.info/revueautrepart-2012-3-page-159.htm>. Accessed: Feb. 02, 2019.

VANDERSYPEN K. Improvement of collective water management in the Office du Niger irrigation scheme (Mali): Development of decision support tools. Doctoraatsproefschrift nr. 750 aan de faculteit Bio-ingenieurswetenschappen van de K.U.Leuven, p.236, 2007.

VANDERSYPEN K. et al. Linking performance and collective action - The case of the Office du Niger irrigation scheme in Mali. Water Resources Management, p.16, 2008. doi: 10.1007/s11269-008-9269-1.

WANNEHAIN. ; JANIN P. Commercialisation des récoltes et disponibilités céréalières des producteurs dans deux « zones greniers » du Mali. Cah Agric, 21:455-64, p.10, 2012. doi: 10.1684/agr.2012.0602.

World Bank- Poverty and shared prosperity. Washington DC 20433, p.201, Word Bank, 2018. doi: 10.1596/978-1-4648-1330-6. 